\title{
ATMOSPHERIC CIRCULATION IN THE CANADIAN HIGH ARCTIC
}

\author{
by
}

Bea T. Alt

(Polar Continental Sinelf Project, Energy, Mines and Resources Canada, 880 Wellington St., Ottawa, Ontario K1A 0E4, Canada)

The high Arctic pollen sites, studied by the Polar Continental Shelf Project (Bourgeois and others 1985), lie in the region dominated by the cold-core westerly circumpolar vortex which is a unique feature of high Arctic atmospheric circulation. The characteristic slow-moving, or quasi-stationary, cold lows of a non-frontal nature, which extend from the surface to the upper atmosphere, produce moisture and aerosol transport conditions which differ considerably from those to the south over southern Baffin Island and the mainland. The geographical position of the transition zone separating these two distinct circulation regimes is now under investigation but it appears to pass between Penny Ice Cap and Bylot Island under present-day summer conditions.

\section{REFERENCE}

Bourgeois J C, Koerner R M, Alt B T 1985 Airborne pollen: a unique air mass tracer, its influx to the Canadian high Arctic. Annals of Glaciology 7: 109-116

\section{SNOW CHEMISTRY ON MOUNT LOGAN, YUKON TERRITORY, CANADA}

\author{
by
}

R.J. Delmas and M. Legrand

(Laboratoire de Glaciologie et Géophysique de l'Environnement du C.N.R.S., B.P. 96, 38402 St.-Martin-d'Hères Cedex, France)

\author{
and G. Holdsworth
}

(National Hydroiogy Research Institute, Environment Canada, Calgary, Alberta T3A 0X9, Canada)

A firn core was recovered in 1980 from an altitude of $5340 \mathrm{~m}$ on Mount Logan $\left(60^{\circ} 36^{\prime} \mathrm{N}, 140^{\circ} 30^{\prime} \mathrm{W}\right)$ and dated $( \pm 0.5$ a) for the last 30 a by oxygen isotope and artificial radioactivity measurements. We present in this note the results of the chemical analysis of a continuous sequence of this core, $11 \mathrm{~m}$ long, cut in 110 individual samples. The time period studied is from 1953 to 1966.

In order to overcome problems of contamination considerable precautions were taken in sample handling and laboratory work. Only the central part of the firn core was melted for chemical analysis. $\mathrm{SO}_{4}^{2-}, \mathrm{NO}_{3}^{-}, \mathrm{Cl}^{-}, \mathrm{Na}^{+}$and $\mathrm{NH}_{4}^{+}$were determined by ion chromatography and strong acidity by a titrimetric method.

Sea-salt contribution (as indicated by $\mathrm{Na}^{+}$ concentrations, average value $1.4 \mathrm{ppb}$ ) was found to be extremely low. All samples were acidic in the range 1-6 req $1^{-1} \mathrm{H}^{+}$. The mineral acids $\mathrm{H}_{2} \mathrm{SO}_{4}$ and $\mathrm{HNO}_{3}$ are the major trace compounds in Mount Logan snow, and occur with about the same concentration $\left(0.9 \mu \mathrm{eq} 1^{-1}\right.$ as an average). Neutralization by $\mathrm{NH}_{3}$ is generally unimportant $(\sim 11 \%$ of the total acidity).

Depth profiles of $\mathrm{SO}_{4}^{2-}, \mathrm{NO}_{4}^{-}, \mathrm{NH}_{4}^{+}$and $\mathrm{H}^{+}$exhibit seasonal patterns with maxima occurring generally in summer. Explosive volcanic eruptions of global concern (such as Mount Agung in 1963 and Bezymianny in 1956) are not recorded. The background acidity of snow at this altitude is assumed to be mainly derived from gaseous $S$ and $\mathrm{N}$ tropospheric compounds, possibly of biogenic origin. In particular our data indicate no clear trend related to the increasing atmospheric acid pollution of the northern hemisphere. 